\title{
DAYA DUKUNG LINGKUNGAN TERKAIT PENGOLAHAN LIMBAH BATIK DI KAMPUNG BATIK GIRILOYO, KABUPATEN BANTUL, YOGYAKARTA
}

\author{
I Gusti Ayu Dwi Muliasari ${ }^{1}$ Widiastuti $^{2}$ \\ 1. Program Studi Magister Teknik Arsitektur, Fakultas Teknik, Universitas Udayana, \\ Jl. P.B. Sudirman, Denpasar \\ 2.Program Studi Arsitektur, Fakultas Teknik, Universitas Udayana \\ Jl. P.B. Sudirman, Denpasar \\ Email: ayudwiwduya@gmail.com,widiastuti@unud.ac.id
}

\begin{abstract}
Abstrak
Yogyakarta merupakan salah satu daerah di Indonesia yang masih mempertahankan warisan budayanya, salah satu warisan budaya yang hingga kini masih menjadi kebanggaan adalah Batik. Warisan budaya ini menjadi semakin diminati oleh banyak orang karena motifnya yang sangat beragam dan biasanya motif batik tersebut menggambarkan ciri khas suatu daerah sehingga dapat dijadikan sebagai buah tangan. Permintaan pasar yang semakin tinggi ini membuat produksi batik semakin meningkat sehingga menimbulkan permasalahan baru yakni pencemaran lingkungan sebagai akibat dari limbah pembuatan batik itu sendiri. Tujuan penelitian ini adalah untuk mengidentifikasi cara pembuangan limbah batik di Kampung Batik Giriloyo, Yogyakarta, dan menganalisis pengaruhnya terhadap kualitas lingkungan. Penelitian ini menggunakan metode penelitian kualitatif dan dengan pendekatan studi kasus. Hasil penelitian menunjukkan bahwa produsen rumahan batik sebagian masih membuang limbahnya secara langsung ke sungai, sebagian lagi membuangnya dalam sumur tanpa filtrasi, dan ada yang telah memiliki tempat pembuangan yang memenuhi standard. Pembuangan di sungai mengakibatkan air sungai yang kotor dan menyebabkan ikan di dalamnya mati. Pembuangan langsung ke tanah mengakibatkan tanaman di sekitarnya mati. Sedangkan pembuangan di dalam sumur tanah tanpa filtrasi menyebabkan pencemaran tanah dan dikhawatirkan mencemari air sumur terdekat.
\end{abstract}

Kata kunci: daya dukung lingkungan, Kampung Batik Giriloyo, limbah batik.

\begin{abstract}
Title: Carrying Capacity Related to Batik Waste Processing in Giriloyo Batik Village, Bantul District, Yogyakarta

Yogyakarta is one of the areas in Indonesia that still maintains its cultural heritage, one of the cultural heritages that is still a source of pride is Batik. This cultural heritage is increasingly in demand by many people because of its very diverse motives and usually these batik motifs describe the characteristics of an area so that they can be used as souvenirs. This higher market demand has made batik production increase, causing new problems, namely environmental pollution as a result of the waste of batik making itself. The purpose of this study was to determine how to dispose of batik waste in Kampung Batik Giriloyo, Yogyakarta, and to analyze its impact on environmental quality. This research uses qualitative research methods with a case study approach. The results showed that some of the batik home producers still dispose of their waste directly into the river, some of them dispose of it in wells without filtration, and some have disposal sites that meet standards. Discharge in the river results in dirty river water and causes the fish in it to die. Direct dumping into the soil causes the surrounding plants to die. Meanwhile, disposal in soil wells without filtration causes soil contamination and there is a concern that it will contaminate nearby well water.
\end{abstract}

Keywords: carrying capacity, Giriloyo Batik Village, batik waste. 


\section{Pendahuluan}

Lingkungan hidup merupakan alam bebas yang terdapat benda, daya, keadaan, dan makhluk hidup, termasuk manusia dan perilakunya. Lingkungan yang ada di muka bumi ini disediakan bukan hanya untuk dinikmati oleh manusia saja, namun juga untuk makhluk hidup yang lain. Manusia merupakan bagian dari lingkungan yang tidak dapat dipisahkan, namun hendaknya manusia dapat menjaga lingkungan terhadap pelestarian, keseimbangan, dan juga keindahan alam tersebut. Pembangunan berkelanjutan merupakan proses pembangunan yang memiliki prinsip dapat memenuhi kebutuhan sekarang tanpa harus mengorbankan kebutuhan dimasa yang akan datang. Dengan adanya perkembangan berkelanjutkan diharapkan tidak hanya memenuhi kebutuhan saat ini saja namun juga dapat memenuhi kebutuhan dimasa yang akan datang sehingga anak dan cucu kita juga dapat menikmatinya.

Daya dukung lingkungan sangat dibutuhkan untuk melindungi lingkungan dan untuk perkembangan berkelanjutan. Daya dukung sendiri mengacu pada pemanfaatan SDA (Sumber Daya Alam) secara maksimum tanpa menimbulkan efek negatif, baik itu dampak negatif bagi penikmat alam maupun bagi masyarakat, ekonomi, serta budaya daerah setempat. Perencanaan daya dukung lingkungan meliputi aspek fisik, biologis, sosial, dan psikologis atau persepsi dari lingkungan itu sendiri.

Indonesia merupakan negara kepulauan yang kaya akan Sumber Daya Alam dan merupakan negara yang kuat akan warisan budayanya, salah satu warisan budaya yang hingga saat ini masih dipertahankan adalah batik. Menurut Santosa Doellah, batik merupakan sehelai kain yang dibuat secara tradisional dan terutama juga digunakan dalam matra tradisional, memiliki beragam corak hias dan pola tertentu yang pembuatannya menggunakan teknik celup rintang dengan lilin batik sebagai bahan perintang warna.

Keberadaan industri batik di Yogyakarta, tepatnya di Desa Wukirsari memiliki sejarah yang panjang, dimana awalnya dimulai dari budaya menggunakan batik oleh Kraton Yogyakarta yang sering digunakan untuk mendukung kegiatan di dalam Kraton dan ketika abdi dalem berkunjung ke Makam Raja-Raja Imogiri. Dimana letak makam raja-raja ini berada diatas Desa Wukirsari sehingga desa tersebut awalnya ditugaskan untuk membuat batik kraton namun seiring perkembangan jaman, Kampung Batik Giriloyo mulai terkenal sebagai sentra kerajinan batik tulis.

Warisan budaya ini menjadi semakin diminati oleh banyak orang karena motifnya yang sangat beragam dan biasanya motif batik tersebut menggambarkan ciri khas suatu daerah sehingga dapat dijadikan sebagai buah tangan. Permintaan pasar yang semakin banyak ini membuat produksi batik semakin meningkat sehingga menimbulkan permasalahan baru yakni pencemaran lingkungan sebagai akibat dari limbah pembuatan batik itu sendiri.

Menurut Undang-Undang No.4 Tahun 1982 tentang Ketentuan-ketentuan Pokok Pengelolaan Lingkungan Hidup, pencemaran lingkungan merupakan proses masuknya atau dimasukkannya mahkluk hidup, zat energi atau komponen lain ke dalam lingkungan 
atau berubahnya tatanan lingkungan sebagai akibat dari perbuatan manusia atau bisa juga karena terjadinya proses alam. Sehingga menyebabkan kualitas lingkungan turun sampai ke tingkat tertentu yang menyebabkan lingkungan menjadi kurang atau bahkan tidak dapat berfungsi lagi sebagaimana mestinya.

Kampung Batik Giriloyo merupakan salah satu sentra kerajinan batik di Yogyakarta yang hingga saat ini masih berjalan dan mengundang wisatawan untuk belajar membatik maupun hanya sekedar berbelanja kain batik hasil produksi pengrajin di Kampung Batik tersebut. Dalam sebulan rumah industri yang ada di Kampung Batik Giriloyo memproses batik minimal dua kali, yang artinya dalam sebulan terdapat dua kali pembuangan limbah bekas pewarnaan kain batik, sedangkan tidak semua rumah industri memiliki alat pengolahan limbah batik, hanya beberapa rumah industri yang sudah memiliki alat pengolahan limbah batik, namun ada juga yang belum memiliki alat pengolahan limbah batik yang menyebabkan tidak semua limbah batik dapat terolah dengan baik.

Terdapat dua limbah hasil dari pembuatan batik, yaitu limbah padat dan limbah cair. Limbah padat meliputi malam hasil dari proses membatik yang dimana malam ini bisa didaur ulang, baik digunakan untuk proses membatik selanjutnya dan juga digunakan sebagai bahan pembuat api. Yang kedua yaitu limbah cair batik, dimana limbah ini sudah tidak dapat diolah kembali sehingga limbah cair bekas pewarnaan dan pencucian batik ini akan dibuang begitu saja ke sungai dan ke sumur. Bila limbah cair ini dibiarkan dibuang begitu saja di sumur maka lama kelamaan limbah ini akan menyerap ke dalam tanah sehingga menyebabkan tanaman disekitarnya akan mati. Dan bila limbah cair ini dibuang ke sungai maka bukan hanya tanaman yang mati, hewan-hewan yang ada di sungai ikut mati.

Upaya penanganan limbah cair batik di Kampung Batik Giriloyo ini sudah lama diperbincangkan dan sudah mengahasilkan beberapa alat pengolahan namun tetap saja ada beberapa rumah produksi yang belum memliki alat tersebut. Diharapkan melalui penelitian ini nantinya pengrajin batik dapat sadar akan pentingnya pengolahan limbah batik sehingga tidak merusak lingkungan dan dapat menjaga lingkungan agar dapat dinikmati hingga seterusnya.

\section{Daya Dukung Lingkungan}

Lingkungan hidup merupakan suatu ruang dimana manusia tinggal, yang didalamnya terdapat pula Sumber Daya Alam seperti air, tanah, flora, dan fauna. Konsep pembangunan berkelanjutan telah menjadi konsep yang terkenal di dunia internasional, pembangunan berkelanjutan dapat diartikan sebagai konsep yang berfungsi untuk memenuhi kebutuhan masa kini tanpa mengorbankan hak pemenuhan kebutuhan-kebutuhan pada generasi yang akan datang. Pembangunan berkelanjutan juga sering dijabarkan dengan perbaikan kualitas hidup yang disesuaikan dengan daya dukung lingkungan. Menurunnya kualitas lingkungan karena terjadinya pencemaran lingkungan sebagai akibat dari limbah cair batik merupakan salah satu ancaman dari pelaksanaan pembangunan berkelanjutan.

Daya dukung lingkungan merupakan batas jumlah penduduk yang dapat didukung tanpa adanya batas waktu tertentu demi tersedianya sumber daya 
dan jasa pendukung modal baik alam, sosial, manusia, dan lingkungan terbangun itu sendiri. Sedangkan menurut Undang-Undang RI No 23 Tahun 1997 tentang Pengelolaan Lingkungan Hidup, daya dukung lingkungan merupakan kemampuan lingkungan hidup untuk mendukung perikehidupan manusia, makhluk hidup lain, dan keseimbangan antar keduanya.

Terdapat beberapa prinsip daya dukung lingkungan agar dapat mendukung lingkungan hidup diataranya yaitu untuk mencapai kelestarian hubungan manusia dengan lingkungan sehingga dapat membangun manusia seutuhnya, mewujudkan manusia sebagai bagian lingkungan hidup dan tidak akan dapat dipisahkan, mengendalikan pemanfaatan sumber daya secara bijaksana dan diolah secara optimal semata demi kesejahteraan masyarakat, serta melaksanakan pembangunan berwawasan lingkungan untuk generasi yang akan datang.

\section{Limbah Batik}

Proses membatik menggunakan lilin dapat menghasilkan sisa lilin ataupun tetesan-tetesan lilin tersebut. Lilin sisa proses membatik ini jika dibuang ke tanah akan mengakibatkan tertutupnya permukaan tanah dan akan mengurangi kemampuan tanah dalam menyerap air. Selain menggunakan lilin untuk menghasilkan kain batik maka diperlukan pula proses pewarnaan, baik pewarnaan secara alami maupun pewarnaan buatan atau sintetis. Proses pewarnaan merupakan proses yang paling banyak menyumbang limbah batik, dimana proses ini banyak menggunakan bahan kimia beracun dan berbahaya. Jika pengolahan tidak dilakukan secara tepat dapat mengakibatkan perubahan warna, tingkat keasaman atau $\mathrm{pH}$, dan pendangkalan air sungai.

Terdapat dua kandungan yang ada pada limbah cair batik yaitu karakteristik fisik dan kimia. Karakteristik fisik yang terdapat pada air limbah batik yaitu adanya kandungan totalsolid yang tersusun dari zat terapung, zat suspensi, zat koloidal, dan zat dalamsalutin, serta bau, temperatur, dan warna. Selanjutnya pada air limbah batik terdapat karakteristik kimia yang meliputi zat organik (protein, karbohidrat, lemak, fenol, pestisida, dan surfactan), zat anorganik (krom $(\mathrm{Cr})$, timbal $(\mathrm{Pb})$, nikel $(\mathrm{Ni})$, tembaga $(\mathrm{Cu})$, mangan $(\mathrm{Mn})$, keasamaan $(\mathrm{pH})$, klorida $(\mathrm{Cl})$, alkali, nitrogen $(\mathrm{N})$, sulfur (S), dll), dan karakteristik biologi (mikroorganisme bersifat patogen dan non patogen). Senyawa logam berat dapat menyebabkan kanker pada makhluk hidup. Selain mengandung senyawa berbahaya, limbah cair batik dapat meningkatkan COD (Chemical Oxygen Demand) dan BOD (Biological Oxygen Demand) air sehingga dapat mengganggu ekosistem perairan. (Aliyuddin \& Wesen)

\section{Metode Penelitian}

Penelitian ini menggunakan metode kualitatif dengan pendekatan studi kasus, karena penelitian ini bersifat unik dan memiliki karakteristik yang berbeda antara yang satu dengan yang lainnya. Siklus penelitian dimulai dengan memilih objek penelitian, yang kemudian dilanjutkan dengan melakukan wawancara seputar objek penelitian tersebut. Selanjutnya mengumpulkan data yang diperoleh dari sesi wawancara dan kemudian menganalisis data tersebut. Proses ini dapat berlangsung beberapa kali tergantung pada lingkup dan 
kedalaman yang diperlukan dalam proses penelitian itu sendiri. (Hardani 2020) Penelitian ini dilaksanakan pada bulan September-Oktober 2020 dengan tujuan untuk melihat pengaruh dari limbah yang dihasilkan dari proses pembuatan batik terhadap kualitas lahan/lingkungan di Kampung Batik Giriloyo tepatnya di Desa Wukirsari, Kecamatan Imogiri, Kabupaten Bantul, Daerah Istimewa Yogyakarta.

\section{Hasil dan Pembahasan}

\section{Gambaran Lokasi Penelitian}

Kampung Batik Giriloyo merupakan sentra kerajinan batik tulis yang ada di Tenggara Yogyakarta (Gambar 1.), tepatnya berada di Dusun Wukirsari, Kecamatan Imogiri, Kabupaten Bantul, Yogyakarta. Kampung batik ini terdiri dari tiga dusun yaitu Dusun Cengkehen, Dusun Giriloyo, dan Dusun Karang Kulon. Secara geografis Kampung Batik Giriloyo berbatasan langsung dengan Dusun Jatirejo, Dusun Karang Asem, Dusun Tilaman, Dusun Kedung Buweng, dan Desa Girirejo. Selain itu Kampung Batik Giriloyo sendiri dilewati pula oleh Kali Giriloyo yang merupakan aliran air dari Air Terjun Seribu Batu. (Gambar 2.)

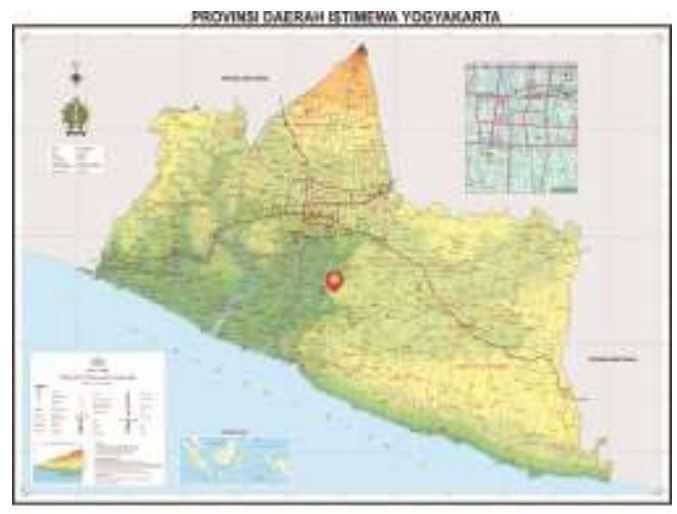

Gambar 1. Lokasi Kampung Batik Giriloyo Sumber: https://peta-kota.blogspot.com/

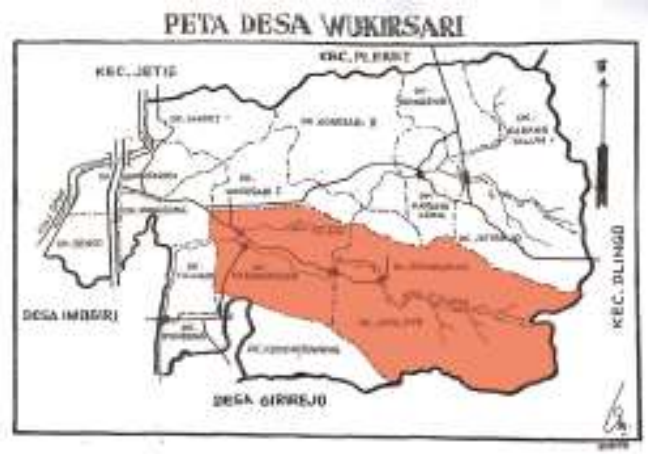

Gambar 2. Peta Desa Wukirsari Sumber: Data Pemerintah Desa Wukirsari, 2019

Untuk menaungi pengrajin dan masyarakat dibentuklah Paguyuban Sentra Kerajinan Batik Tulis Giriloyo yang terdiri dari 12 kelompok pengrajin batik dengan masing-masing kelompok terdiri dari 50 hingga 100 orang pengrajin. Hasil karya pengrajin akan dipasarkan melalui showroom yang ada di Gazebo Batik (Gambar 3.) yaitu di Dusun Karang Kulon, dengan begitu pengrajin akan lebih mudah untuk memasarkan hasil karyanya. Selain 12 kelompok tersebut terdapat delapan industri rumahan yang berdiri sendiri. Meskipun mereka berdiri sendiri atau tidak ikut dalam Paguyuban Sentra Kerajinan Batik Tulis Giriloyo, mereka tetap memasarkan hasil karyanya ke Gazebo Batik.

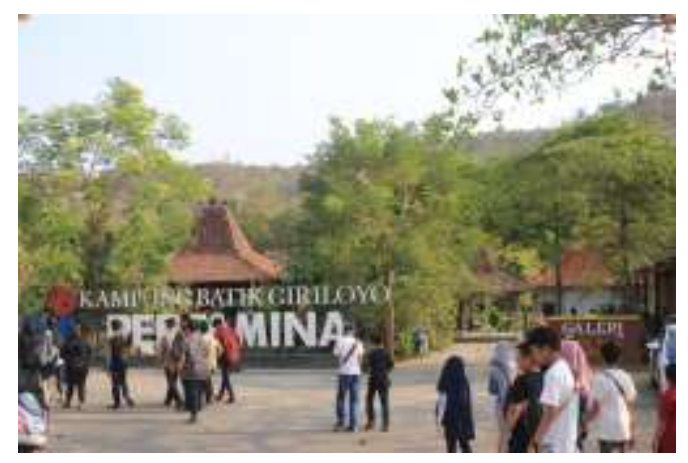

Gambar 3. Gazebo batik Sumber: Observasi lapangan, 2019 
Berdasarkan tinjauan lokasi dan wawancara terhadap pengelola dan pengrajin batik di Kampung Batik Giriloyo, maka didapatkan hasil sebagai berikut:

1. Dalam satu tahun Gazebo Batik menerima kunjungan mencapai 600 orang dalam satu waktu, yang biasa terjadi dua hingga tiga kali kunjungan. Dimana dari tahun ke tahun jumlah pengunjung tersebut semakin meningkat. Pengunjung tidak hanya membeli batik, namun juga ikut belajar membatik.

2. Terdapat 12 kelompok industri rumahan yang tergabung dalam Paguyuban Sentra Kerajinan Batik Tulis Giriloyo dan terdapat delapan kelompok yang berdiri sendiri dan empat diantaranya belum memiliki sistem pengolahan limbah batik yang baik, yaitu Mutiara Batik, Fajar Batik, Sidomukti Batik, dan Sukamaju Batik.

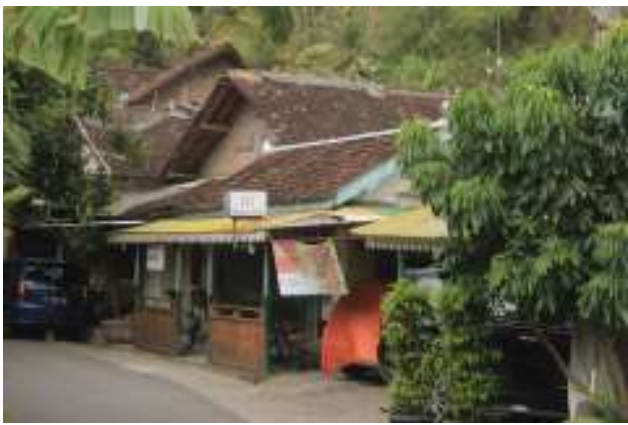

Gambar 4. Industri rumahan

Sumber: Observasi lapangan, 2020

3. Proses membatik yang ada di Kampung Batik Giriloyo dilakukan melalui tujuh tahapan, yang pertama terdapat tahap memola dimana tahapan ini dapat dilakukan dengan dua cara yaitu menggambar pola di kertas terlebih dahulu atau langsung ke kain. Kedua, tahap klowong yaitu tahap mencanting kerangka motif batik. Ketiga, tahap isen-isen yaitu tahap memberi isi kedalam rangka motif batik yang telah dilakukan ditahap kedua. Keempat, tahap menembok yaitu menutup bagianbagian yang diinginkan dengan malam agar pada proses pewarnaan nantinya warna tersebut tidak masuk dan menghasilkan kain batik yang tidak sesuai harapan. Kelima, tahap pewarnaan yang terdapat dua pewarna yang digunakan yaitu pewarna sintetis dan pewarna alami. Penggunaan pewarna alami hanya dilakukan ketika mendapat pesanan, sedangkan pewarna yang sering digunakan adalah sintetis menggunakan naptol dan indigosol. Dan yang terakhir tahap keenam yaitu tahap pelodoran (Gambar 5.), pelodoran merupakan tahap menghilangkan sisa malam yang menempel diatas kain. Proses ini dilakukan dengan menggunakan soda abu agar memudahkan malam lepas dari kain, yang nantinya malam tersebut dikumpulkan lalu dapat digunakan kembali.

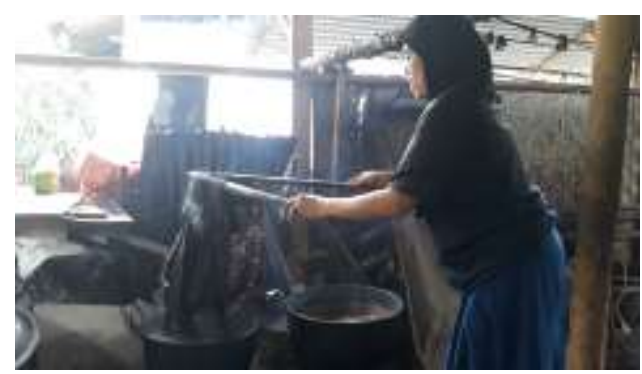

Gambar 5. Tahap pelodoran

Sumber: Observasi lapangan, 2020

4. Para pengrajin yang ada di Kampung Batik Giriloyo menggunakan dua teknik pewarnaan yaitu menggunakan pewarna alami dan pewarna sintetis, dimana pewarna sintetis sendiri akan menghasilkan limbah cair batik yang berbahaya. 


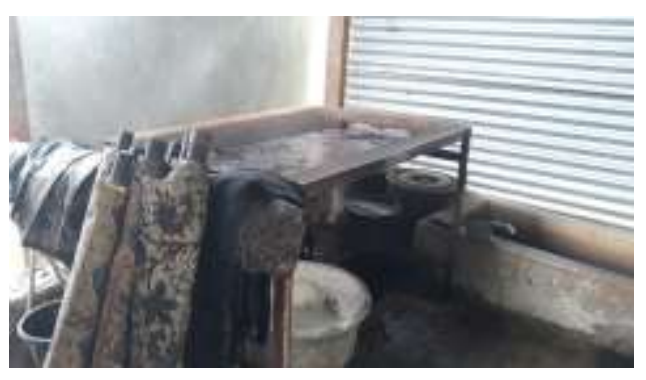

Gambar 6. Alat yang digunakan untuk pewarnaan kain batik

Sumber: Observasi lapangan, 2020

5. Terdapat dua jenis limbah yang dihasilkan dari proses membatik, yaitu limbah padat dan limbah cair. Limbah padat (Gambar 7.) sudah terkelola dengan baik dimana limbah tersebut dapat digunakan kembali untuk dijadikan bahan untuk menyalakan api atau dalam bahasa jawa biasa disebut daden geni. Namun untuk limbah cair belum dikelola dengan baik, ada yang dibuang ke sungai dan ada juga yang langsung diserapkan ke dalam tanah tanpa melalui proses netralisasi.

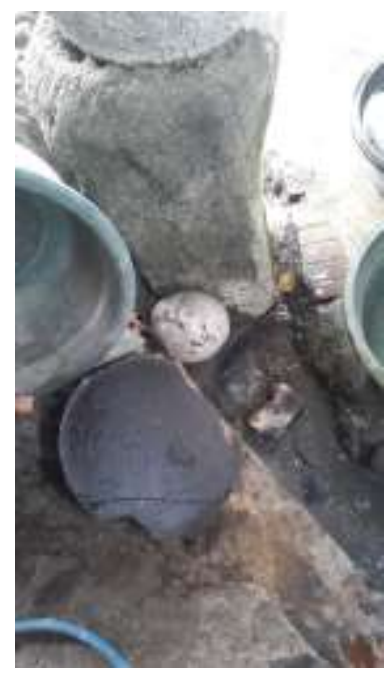

Gambar 7. Limbah padat batik Sumber: Observasi lapangan, 2020

6. Gazebo Batik memiliki alat pengolahan limbah yang sudah setara nasional namun sayangnya tidak banyak digunakan karena proses membatik di Gazebo hanya untuk wisatawan dalam artian hanya lingkup kecil. Sedangkan proses pembuatan batik dilakukan di rumah-rumah industri yang belum memiliki alat pengolahan limbah batik sesuai standar yang ada.

\section{Pengaruh Limbah Cair Batik Terhadap Lingkungan}

Berkah dari pembuatan batik di Kampung Batik Giriloyo berbanding terbalik dengan dampak yang ditimbulkannya. Semakin tingginya permintaan pasar maka semakin banyak pula limbah yang dihasilkan dan akan menimbulkan permasalah baru yakni pencemaran lingkungan sebagai akibat dari limbah pembuatan batik itu sendiri. Menurunnya kualitas lingkungan sebagai dampak dari proses membatik adalah salah satu acaman dari pelaksanaan pembangunan berkelanjutan.

Limbah cair batik yang dibuang begitu saja ke lingkungan akan memberikan dampak negatif, maka perlu adanya daya dukung lingkungan agar dapat mendukung lingkungan hidup diataranya yaitu untuk mencapai kelestarian hubungan manusia dengan lingkungan sehingga dapat membangun manusia seutuhnya, mewujudkan manusia sebagai bagian lingkungan hidup dan tidak akan dapat dipisahkan, mengendalikan pemanfaatan sumber daya secara bijaksana dan diolah secara optimal semata demi kesejahteraan masyarakat, serta melaksanakan pembangunan berwawasan lingkungan untuk generasi yang akan datang. 


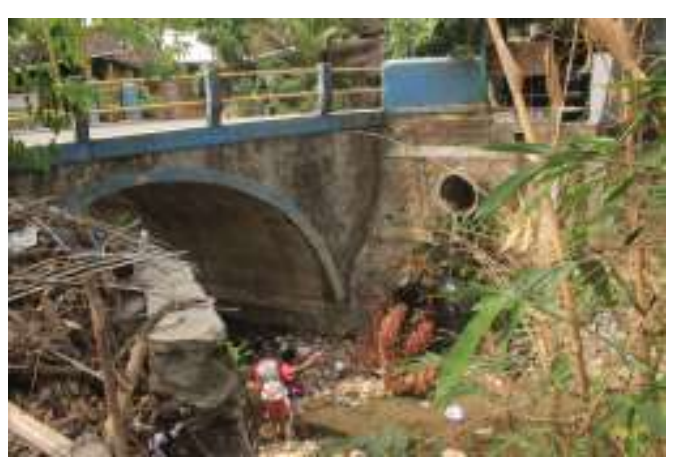

Gambar 8. Kondisi Kali Giriloyo

Sumber: Observasi lapangan, 2020

Namun yang terjadi di lapanganan, pengrajin batik ini membuang limbah cair batik sisa proses pembuatan batik begitu saja ke lingkungan. Seperti yang dilakukan oleh salah satu rumah industri, mereka membuang sisa limbah pembuatan batik ke Kali Giriloyo yang menyebabkan biota air yang ada di sungai tersebut mati. Kejadian seperti ini sudah dilaporkan ke Kepala Dusun dan pihak pengrajin sudah ditegur.

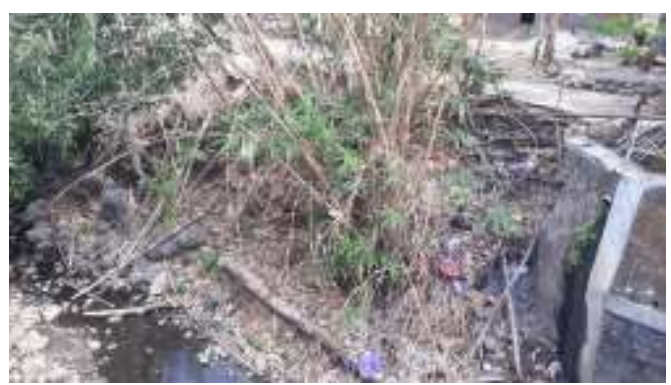

Gambar 9. Kondisi Kali Giriloyo Sumber: Observasi lapangan, 2020

Selain dibuang ke sungai, yang dilakukan oleh dua industri rumahan yang lain yaitu dengan menyalurkan limbah cair tersebut ke dalam sumur resapan tanpa alat filtrasi, jadi langsung begitu saja diresapkan ke sumur tanpa melalui proses apapun. Jika kejadian ini dibiarkan maka lama kelamaan tanah tersebut akan tercemar dan nantinya akan menimbulkan bau tak sedap. Selain bau, limbah cair batik ini juga akan merusak lingkungan, tanaman akan mati dan parahnya lagi jika limbah ini sampai ke sumur air bersih maka orang-orang yang menggunakan sumur tersebut akan merasakan dampaknya seperti terganggunya kesehatan. Terutama penyakit yang menyerang kulit, mata, dan hidung.

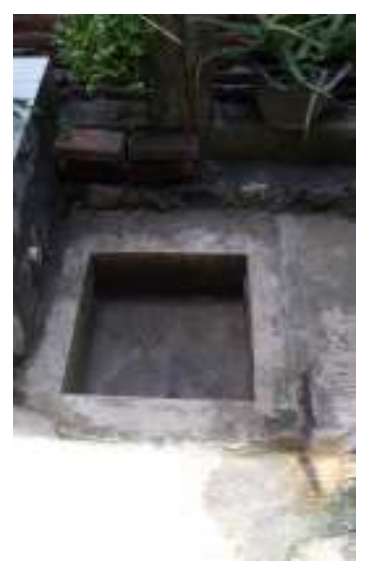

Gambar 10. Bak penampungan limbah cair batik sebelum disalurkan ke sumur Sumber: Observasi lapangan, 2020

\section{Kesimpulan}

Dari penelitian yang telah dilakukan dapat dilihat bahwa sebagian industri rumahan yang ada di Kampung Batik Giriloyo belum memiliki alat pengolahan limbah cair batik yang sesuai dengan standar. Meskipun hanya sebagian yang belum memiliki alat pengolahan tetapi jika produksi batik ini terus dilakukan maka seiring berjalannya waktu akan menurunkan kualitas lingkungan. Dengan dikelolanya limbah cair batik dengan benar diharapkan dapat mengendalikan kualitas limbah cair batik yang dibuang ke lingkungan atau ke sungai. Selain itu juga dapat menjaga, melindungi, dan mempertahankan kualitas air baik itu air yang ada di sungai maupun air yang ada di tanah sehingga dapat 
berfungsi sesuai dengan peruntukannya. Dan juga yang tidak kalah pentingnya yaitu untuk meningkatkan kualitas lingkungan dalam mewujudkan daya dukung lingkungan terhadap pembangunan berkelanjutan.

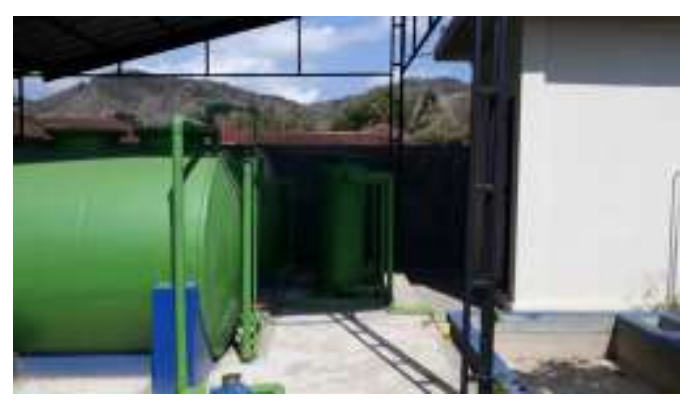

Gambar 11. Alat pengolahan limbah cair yang sudah sesuai standar

Sumber: Observasi lapangan, 2020

\section{Ucapan Terima Kasih}

Penulis mengucapkan terimakasih yang sebesar-besarnya kepada:

1. Pengelola Paguyuban Batik Giriloyo, Desa Wukirsari, Kecamatan Imogiri, Kabupaten Bantul, Yogyakarta atas waktu, kesempatan, dan bantuannya selama penulis melakukan penelitian.

2. Universitas Udayana khususnya Program Studi Magister Arsitektur atas dukungan dan bimbingannya sehingga dapat menyelesaikan penelitian ini dengan baik.

\section{Daftar Pustaka}

Hardani, Nur Hikmatul, A., Helmina, A., Roushandy, A.F., Jumari, U., Evi, F.U., Dhika, J.S., Ria, R.I. (2020). Metode penelitian kualitatif \& kuantitatif. Yogyakarta: CV. Pustaka Ilmu Group.
Kurniawan, M. W., Purwanto, P., Sudarno, S. (2013). Strategi pengelolaan air limbah sentra UMKM batik yang berkelanjutan di Kabupaten Sukoharjo. Jurnal Ilmu Lingkungan, 11(2): 62-72.

Muliasari, I. G. A. D. (2019). Pusat informasi pariwisata dan amenitas kampung batik giriloyo, dusun karang kulon, desa wukirsari, kecamatan imogiri, kabupaten bantul. (Skripsi S1, Universitas Atma Jaya Yogyakarta, 2019. Tidak dipublikasikan).

Republik Indonesia. (1997). UU no. 23/1997 tentang pengelolaan lingkungan hidup. Jakarta: Presiden RI. 